\title{
Republicanismo, clientelas y prácticas caciquiles en Asturias (1868-1911)
}

\author{
Sergio SÁnChez Collantes \\ Universidad de Oviedo \\ koyu79@hotmail.com
}

Recibido: 04/05/2013

Aceptado: 10/06/2013

\section{RESUMEN}

Este trabajo analiza los vínculos que hubo entre los republicanos y el caciquismo en Asturias durante el último tercio del siglo XIX y los inicios del XX. Los distintos partidos republicanos fustigaron siempre el caciquismo, juzgándolo uno de los grandes males del país. Sin embargo, algunas organizaciones y personalidades no dejaron de incurrir en las mismas prácticas que denunciaban, como partes integrantes de un sistema de relaciones clientelares que no era fácil sortear. Ilustraremos este fenómeno mediante el estudio de las denuncias de los afectados, la correspondencia privada y otras evidencias contenidas en diversas fuentes primarias y bibliográficas.

Palabras clave: Republicanismo, caciquismo, partidos políticos, elecciones, clientelas, recomendaciones.

\section{Republicanism, Patron-Client Networks and Caciquism in Asturias (1868-1911)}

\begin{abstract}
This paper analyzes the links between republicanism and caciquism in Asturias from 1868 to 1911. All republican parties criticized caciquism harshly, considering it as one of the country's biggest problems. Nevertheless, some of them never ceased doing precisely what they denounced, establishing a patronage system which was almost impossible to bypass, as can been seen through the numerous complaints written by affected individuals, the private correspondence of prominent republicans as well as other primary and bibliographical sources.
\end{abstract}

Key words: Republicanism, Caciquism, Political Parties, Elections, Patronage System, Recommendations.

Referencia normalizada: Sánchez Collantes, Sergio (2013). "Republicanismo, clientelas y prácticas caciquiles en Asturias (1868-1911). Cuadernos de Historia Contemporánea, vol.: 35, pp. 137-160.

Sumario: Introducción. 1. El republicanismo los abusos y la influencia. 2. El uso habitual de las recomendaciones. 3. La base clientelar de los triunfos de José María Celleruelo. 4. Otros republicanos en entredicho. 5. Conclusiones. Agradecimientos. 


\section{Introducción}

A propósito del caciquismo español se han realizado infinidad de estudios. El caso de Asturias todavía reclama una investigación sistemática que profundice en sus orígenes y desarrollo, pero existen trabajos que han contribuido en distinto grado a iluminar varios aspectos fundamentales ${ }^{1}$. Lo que sigue constituyendo un fenómeno bastante desconocido en España es la participación directa o indirecta de los republicanos en ese fenómeno sociopolítico y en las redes clientelares.

Las invectivas de los republicanos contra las prácticas caciquiles fueron un elemento omnipresente en sus artículos, discursos, mítines, folletos doctrinales y obras literarias. No parece necesario recopilar juicios de todo ello porque es algo bien sabido. La censura de las prácticas electorales y del falseamiento sistemático de la opinión, junto con el parlamentarismo y los fundamentos doctrinarios del régimen, como ha explicado Manuel Suárez Cortina, "conformaron el eje de la crítica política republicana". Aunque había una diversidad de corrientes manifiesta, generalmente compartieron ese rechazo del fraude, ya que convertía el parlamento en una cámara sin ningún valor representativo ${ }^{2}$.

¿Qué ha dicho la historiografía sobre el uso republicano de esos procedimientos tan denostados por los publicistas del regeneracionismo? Algunos trabajos han suministrado datos esclarecedores acerca de esta cuestión, mencionada, no obstante, de forma muy tangencial. Demetrio Castro ha llamado la atención sobre el carácter de los distritos por los que los demócratas obtuvieron buena parte de los dieciséis escaños logrados en las constituyentes de 1854. Se trataba de provincias "acusadamente rurales y deprimidas" (León, Palencia, Salamanca, Cáceres y Huesca). De ello infiere que, "con toda claridad, ese voto fue un voto clientelista, atraído por notabilidades locales con control sobre redes de influencia" (el conde de las Navas, García Ruiz, Orense...). Por el contrario, en poblaciones como Madrid, Barcelona, Valencia, Bilbao u Oviedo, según apunta Carlos Dardé, los triunfos en las elecciones a Cortes de la Restauración estaban por lo general "ligados a la difusión de los valores y la

\footnotetext{
* Abreviaturas utilizadas: ACD (Archivo del Congreso de los Diputados), AHA (Archivo Histórico de Asturias), AHFAM (Archivo Histórico de la Fundación Antonio Maura), FAMM (Fondo Antonio Maura Montaner), FDP (Fondo de la Diputación Provincial), FPH (Fondo de José Posada Herrera) y FCC (Fondo de la Casa Celleruelo).

${ }^{1}$ En orden cronológico, se trata de los estudios de GARCÍA, Carmen: Elecciones y partidos en Asturias a mediados del siglo XIX (1854-1868), Memoria de licenciatura, Universidad de Oviedo, 1979; GIRÓN, José: Elecciones y partidos politicos en Asturias, 1890-1936, Tesis doctoral, Universidad de Oviedo, 1981; GARCÍA CALZÓN, María Luisa: El Sexenio democrático en Asturias (1868-1875), Memoria de licenciatura, Universidad de Oviedo, 1983; y LANA ARIAS, Manuel: Elecciones y caciquismo en Asturias (1875-1890), Memoria de licenciatura, Universidad de Oviedo, 1986. Lamentablemente, dichas investigaciones permanecen inéditas, aunque de las tres primeras vieron la luz sendos resúmenes en Historia General de Asturias, tomo 4, Gijón, Silverio Cañada, 1978, pp. 113-128, 161-176 y 209-224. A los trabajos mencionados cabría sumar el balance de GARRIDO, Aurora: “Asturias”, en José VARELA ORTEGA (dir.), El poder de la influencia. Geografía del caciquismo en España (1875-1923), Madrid, Marcial Pons-CEPC, 2001, pp. 65-84.

2 SUÁREZCORTINA, Manuel: "Radicalismo y reformismo en la democracia española de la Restauración", Berceo, 39 (2000), p. 53; "El institucionismo y la cultura política republicana en la Restauración”, en Fernando MARTÍNEZ LÓPEZ (ed.): Nicolás Salmerón y el republicanismo parlamentario, Madrid, Biblioteca Nueva, 2007, pp. 195-196.
} 
cultura republicanos". Aun así, matiza que "en muchos resultados favorables de capitales de provincia también pesaron las prácticas fraudulentas", sobre todo en las secciones rurales de las circunscripciones. De manera que, según explica este autor, Gumersindo de Azcárate en León y José Muro en Valladolid, por ejemplo, “formaban parte del encasillado gubernamental y disponían de una «máquina doble» en la ciudad y en el campo, basada en la opinión y el voto obrero, en un ámbito, y en el cultivo de las clientelas personales en el otro". Esas clientelas también resultaron decisivas para las actas conseguidas en Alicante (por Eleuterio Maisonnave), en Badajoz (Eduardo Baselga), en Almería (Juan Anglada), en Huesca (Manuel Camo) y en Málaga (José Carvajal). Lo mismo podría decirse de José Montes Sierra, diputado por Sevilla en los primeros años del novecientos, que terminó incluido en el encasillado ${ }^{3}$.

En los casos mencionados, pues, llegaban a ser irónicas denuncias como la siguiente, de Rafael María de Labra: "nadie ignora que (...), en la ley electoral, se han creado las circunscripciones electorales para dominar con los votos de las aldeas y del campo, las fuerzas republicanas de las poblaciones de importancia". Porque, según ha explicado Dardé, el control electoral republicano de algunos distritos rurales "no se debía al arraigo de la opinión", sino que "estaba dominada por cuestiones locales e influencias personales". Refiriéndose ya a la segunda década del siglo XX, Suárez Cortina también ha recordado que, especialmente los sectores afines al reformismo, "no tuvieron problema en establecer mecanismos clientelares, de naturaleza muy semejante a aquella desarrollada por el sistema", lo cual hicieron gracias al artículo 29 "o desde una red clientelar propia que competía en algunos distritos y circunscripciones con las redes del sistema". De ahí la existencia de personajes como el que describió Ciges Aparicio, supuestamente ficticio: el sobrino de un ex-ministro de la República que, debido a ese vínculo, hacía carrera sin esfuerzo ("Por influencias del tío es profesor auxiliar de la Universidad; ahora le harán concejal; será luego diputado..."). Como razona Javier Moreno Luzón, aunque los políticos fueran conscientes de los graves problemas que las prácticas clientelares generaban en el funcionamiento del Estado, "los partidos — incluida la oposición republicana moderada- continuaron constituyendo clientelas de notables y caciques, poco dispuestas a perder sus prebendas"4.

3 CASTRO, Demetrio: "Unidos en la adversidad, unidos en la discordia: el Partido Demócrata, 18491868", en Nigel TOWNSON (ed.): El republicanismo en España (1830-1977), Madrid, Alianza, 1994, p. 68. DARDÉ, Carlos: "La larga noche de la Restauración, 1875-1900", en Nigel TOWNSON: El republicanismo..., p. 130; "El movimiento republicano. Los hombres, los partidos, los programas y la práctica política", en Manuel ESPADAS BURGOS (coord.), La época de la Restauración (1875-1902). Estado, Política e Islas de Ultramar, en Historia de España Menéndez Pidal, tomo XXXVI, vol. I, Madrid, Espasa Calpe, 2000, p. 559. LÓPEZ VILLA, Antonio: "José Montes Sierra y el republicanismo sevillano a comienzos del siglo XX", en José Luis CASAS SÁNCHEZ y Francisco DURÁN ALCALÁ (eds.), El republicanismo ante la crisis de la democracia. Una perspectiva comparada (1909-1939), Córdoba, Diputación de Córdoba y Patronato Niceto Alcalá-Zamorá, 2010, pp. 343-362.

4 LABRA, Rafael M. de: "El partido republicano en España", en El Avance, Gijón, 5-III-1900. DARDÉ, Carlos: "El movimiento...", p. 561. SUÁREZ CORTINA, Manuel: "Entre la barricada y el Parlamento. La cultura política republicana en la Restauración”, en Manuel SUÁREZ CORTINA (ed.): La cultura española en la Restauración, Santander, Sociedad Menéndez Pelayo, 1999, p. 522 (según el artículo 29, cuando había un solo candidato se le podía proclamar diputado sin verificarse la elección). CIGES APARICIO, Manuel: $\mathrm{Del}$ periódico y de la política, Madrid, Librería de los Sucesores de Hernando, 1907, pp. 214 y 218. MORENO 
Los diferentes estudios locales y regionales pueden contribuir a dibujar ese mapa de la influencia republicana en el conjunto de España, que no sólo debe prestar atención al manejo o falseamiento de las luchas electorales, sino también a fenómenos como las recomendaciones y el intercambio de favores sensu lato. Naturalmente, la participación fue muy desigual según la agrupación republicana o los dirigentes que se analicen; y los beneficios, muy inferiores a los que obtuvieron los partidos del turno, algo bien demostrado por la limitada representación que consiguieron en las instituciones supralocales.

\section{El republicanismo, los abusos y la influencia}

Las quejas sobre la actuación de ciertos republicanos en tiempo de elecciones se documentan ya en los comicios verificados por sufragio universal masculino tras la revolución de 1868. Por lo general, fueron los republicanos quienes más protestaron contra los abusos, pero algunas veces se convirtieron en el objeto de las críticas. En 1873, de hecho, se lanzaron acusaciones entre ellos mismos. En Oviedo, por ejemplo, Vicente Rubiera impugnó el triunfo de José González Alegre, manifestando que se había presionado a muchos electores y que el hermano del ganador había visitado las parroquias del municipio y en ellas había prometido servicios y ofertas. De acuerdo con su versión, algunos empleados del municipio tomaron parte en la elección y ciertos partidarios "maltrataron a varios ciudadanos" y negaron "el talón o cédula de sufragio a un sinnúmero", llegando al extremo de amenazar "en todos los tonos con despedazar las urnas si no salía vencedor". Hubo probados federales que testificaron a favor de esta denuncia, como José Ramón Melendreras y Wenceslao Guisasola, quienes aseguraron haber sido "algunos de los que llevaron los golpes". En Laviana se denunció también el empleo de "garrotes y coacciones", y un vecino dijo haber presenciado el ataque del que fue víctima un ciudadano "repentinamente acometido por una turba" en la que estaba el republicano Facundo Valdés ${ }^{5}$.

Naturalmente, acusaciones como éstas no pueden elevarse a la categoría de hechos probados, y contrastarlas hoy en día es tarea poco menos que imposible. Ahora bien, existen otras fuentes relativas a esas mismas elecciones que demuestran que hubo republicanos que, con el fin de asegurarse la victoria, no tuvieron objeciones morales a la hora de acudir a las redes clientelares tradicionales. Se trata de la correspondencia personal, siempre reveladora de matices inexistentes en otra clase de documentación. Sirva para ilustrar este supuesto la figura de Vicente Caso Díaz, que profesó ideas federales toda su vida y que obtuvo el acta de diputado a Cortes por Llanes en las constituyentes de 1873. Antes de verificarse los comicios, le dirigió una carta a José Posada Herrera mediante la cual intentó recabar su apoyo. Buscaba el respaldo de quien, siendo ministro de la Gobernación en el periodo tardoisabelino, precisamente

LUZÓN, Javier: "«El poder público hecho cisco». Clientelismo e instituciones políticas en la España de la Restauración", en Antonio ROBLES (comp.): Política en penumbra. Patronazgo y clientelismo políticos en la España contemporánea, Madrid, Siglo XXI, 1996, pp. 189-190.

5 Se trata de referencias del Libro de Registro de Elecciones del ACD, citadas en GARCÍA CALZÓN, María Luisa, El Sexenio..., pp. 202-203 y 225. 
se había ganado el apodo de El Gran Elector. Cauteloso en sus palabras, escribió Caso:

Muy Sr. mío y amigo: Compromisos políticos, de los que no me es dable prescindir, me obligan a presentarme como candidato (...).

Como Republicano de orden, y por consiguiente enemigo irreconciliable de toda idea disolvente y anárquica, me hallo identificado con la política del Gobierno que hoy preside los destinos de España.

Para apoyar a este Gobierno y sostener en toda su pureza los principios Republicanos de libertad, orden y justicia igual para todos, necesito del concurso, no sólo de los hombres que militan en mi partido, sino muy especialmente del de mis particulares amigos y convecinos; y siendo V. uno de éstos me atrevo a suplicarle favorezca con su voto e influencia mi candidatura 6 .

Tantear la disposición de un notable o cacique no significa que el demandante de amparo lo fuese, pero sí quedaba introducido en una maquinaria donde los favores no se concedían de balde, pues eran justamente las contraprestaciones las que articulaban el engranaje. Ahora bien, ni ese comportamiento se generalizó entre los republicanos, ni ellos devinieron sus principales beneficiarios. En el caso mencionado, de hecho, Posada Herrera respondió negativamente ${ }^{7}$.

De la Restauración se conservan testimonios similares a los antedichos que contienen, o bien acusaciones de irregularidades, o bien el deseo más o menos explícito de beneficiarse de la influencia de un notable. Tras las elecciones municipales de 1885, por ejemplo, el periodista Agustín Laruelo denunció que en el colegio ovetense en el que se había presentado, y donde triunfó el elemento republicano, "aparecieron votando respetables Canónigos de la Santa Iglesia Catedral que no concurrieron a la elección, (y) enfermos que, en el acto de ella, permanecían en cama"8. Determinar la veracidad de tales inculpaciones vuelve a resultar complicado, porque además era notorio el fuerte apoyo que tenían las candidaturas democráticas en Oviedo, reconocido incluso por sus adversarios. Ese respaldo hizo posible que, desde finales de los setenta, las candidaturas de la Unión Democrática lograran victorias que les aseguraron continuas mayorías en el Consistorio. Así que la pregunta que cabe formular es otra: ¿cómo distribuyeron los numerosos empleos que dependían del Ayuntamiento?

Efectivamente, como ha recordado Moreno Luzón, existía todo un conjunto de puestos de los que disponían los consistorios para ofrecer a los adictos, o sea, que estaban sujetos a "decisiones de carácter político". Hablamos de guardias municipales, vigilantes de consumos, trabajos en las obras públicas, personal sanitario, oficinistas, etcétera. De ahí que Víctor Polledo manifestase que, nada más triunfar la Gloriosa en Oviedo, "los progresistas y demócratas eran dueños ya de todos los poderes públicos, y por lo tanto de todos los puestos ídem". Según este miembro de la Unión Liberal,

6 AHA-FPH, Caja 11.410, Leg. 38, n 59 (carta fechada en Llanes el 19-IV-1873; la cursiva es nuestra).

7 AHA-FPH, Caja 11.410, Leg. 38, n 59 (carta de Posada Herrera a V. Caso, fechada en Llanes el 24-IV1873): “(...] apartado hace años de la política y mucho más de las cuestiones locales a que da origen, de nada puedo servir a V. en las futuras elecciones, aun en el supuesto de que no se presenten personas más conformes con mis opiniones respecto de la forma de gobierno".

8 El Carbayón, Oviedo, 9-V-1885. 
desde ese momento se consagraron a "decretar cesantías y destituciones a tuti-plen", a fin de "acallar modestas exigencias populares con plazas de serenos, municipales, porteros de las oficinas públicas, conserjes y otros puestos de escalera abajo". De tal manera ocurrió así, que "hasta altas horas de la noche (...) fueron los salones, oficinas y pasillos del caserón municipal un hormiguero de pretendientes con derechos indiscutibles"?.

Como reflejó en su día Ciges Aparicio, no debieron de faltar ediles republicanos que fueran "caciquillos en sus distritos"; incluso, por elegir candidatos inapropiados, a veces resultaron consistorios de rectitud dudosa ("donde la ineptitud y la inmoralidad republicanas han rivalizado con las monárquicas en momentos de prueba"). En otras regiones sucedió lo mismo. Gregorio de la Fuente Monge ha explicado que, durante el Sexenio, en algunas ciudades el partido republicano "aventajó a otras fuerzas políticas en el ensayo de crear nuevas clientelas"; y que semejante red se tejió "desde los ayuntamientos, recurriendo a métodos conocidos: las milicias civiles, las obras públicas, la redención de quintos, el asociacionismo, a veces el boicot fiscal, etcétera" 10 .

Álvarez Junco ha concluido que "puede decirse que los ayuntamientos españoles vivían, de manera habitual, en la ilegalidad", al menos en el sentido de incumplir sistemáticamente sus funciones por la precariedad de medios económicos, administrativos y humanos. No es fácil aquilatar el grado de desarrollo que alcanzaron las clientelas en el municipio ovetense durante los años en los que los republicanos fueron mayoría, pero negarlas - aun considerando que el alcalde fuera de real ordenequivale a divorciar el concejo de la realidad social en la que se hallaba inmerso. No por casualidad, la figura del cesante era un elemento típico del paisaje social, bien reflejado en los testimonios literarios costumbristas y realistas ${ }^{11}$.

En el mismo sentido, habría que desentrañar las secuelas que tuvo en la vida local la forma de organización y articulación de los Voluntarios de la Libertad y los de la República, fuerzas ciudadanas que, como ha escrito Pere Gabriel, también "escondían bastante claramente caudillismos y reclutamientos clientelares". Extrapolando esa hipótesis a Asturias, cabría preguntarse qué motivos, aparte de los puramente ideológicos, empujaron a tantos republicanos a secundar a oficiales de los Voluntarios como Bernardo Coterón, Antonio Rodil y Valeriano Díaz Vigil en sus temerarias intentonas armadas. ¿Les movió sólo la utopía de la Federal o se vieron arrastrados por lealtades personales complejas de tipo clientelar? ${ }^{12}$

9 MORENO LUZÓN, Javier: “El poder...”, pp. 173-174. "Recuerdos locales”, en El Correo de Asturias, Oviedo, 27-III y 18-IV-1895.

10 CIGES APARICIO, Manuel: Del periódico..., pp. 221-222: "Hay tres o cuatro concejales inteligentes; los demás son beocios, toscos y blasfemos, caciquillos en sus distritos, prófugos algunos de los partidos monárquicos". FUENTE MONGE, Gregorio de la: "Élite política y clientelismo durante el Sexenio Democrático (1868-1874)", en Antonio ROBLES (comp.), Política ..., p. 136.

11 ÁLVAREZ JUNCO, José: "Redes locales, lealtades tradicionales y nuevas identidades colectivas", en Antonio ROBLES (comp.), Política ..., pp. 73-74. ALBUERA GUIRNALDOS, Antonio: "El cesante: análisis de un "tipo" social del siglo XIX", Cuadernos de Historia Contemporánea, 12 (1990), pp. 45-66.

12 GABRIEL SIRVENT, Pere: "Insurrección y política. El republicanismo ochocentista en Cataluña", en Nigel TOWNSON (ed.), El republicanismo..., p. 353. SÁNCHEZ COLLANTES, Sergio: Sediciosos y ro- 
Aspecto diferente es la búsqueda de la influencia de un notable, que para el Sexenio hemos ilustrado con la actitud de Vicente Caso. En 1883, por ejemplo, volvió a pretenderse que el ascendiente de Posada Herrera beneficiara a la democracia local, pero de forma indirecta y bastante más hábil. Los republicanos de la capital asturiana gozaban de mayoría en el Ayuntamiento desde finales de los setenta, momento en que consiguieron el triunfo de su candidatura de Unión Democrática, una alianza pionera que resultó de la coordinación de fuerzas ${ }^{13}$. Sin embargo, el alcalde era nombrado por Real Orden, lo que limitaba sustancialmente el margen de actuación de los ediles demounionistas. Pues bien, en tales circunstancias, la estrategia que aplicaron consistió en intentar atraer a su candidatura a una persona que gozara del favor de otra poderosa, en este caso el llanisco Posada Herrera, para luego sugerirla como alcalde y desalojar así a José Longoria, quien desempeñaba el cargo. Y el vecino idóneo resultó ser Genaro Alas, el hermano de Clarín, en el que despertaba simpatías el republicanismo castelarino ${ }^{14}$. Avalan esta hipótesis la correspondencia privada y otros testimonios. Por lo pronto, la prensa comunicó la singular posición de Alas en la candidatura: "aunque presentado y apoyado por los demócratas, es independiente". Y él mismo se lo detalló a su protector en una carta mediante la que, además, le solicitaba su beneplácito:

Una comisión (...) vino a informarme que habían acordado darme un lugar preferente en su candidatura haciendo respecto a mí abstracción completa de la política, pues su intento era presentar al Gobierno una persona que le mereciese confianza para Alcalde, y ellos deseaban que yo lo fuese, porque se contentaban con no ser objeto de una hostilidad sistemática por parte de la autoridad local. Yo me resistí una y dos veces a dar mi consentimiento, pero tanto y de tal modo me estrecharon que al fin cedí, a condición empero, les dije, de que el Sr. Posada Herrera, a cuyo lado estoy siempre, lo apruebe y esté dispuesto a apoyar mi candidatura para Alcalde ante el ministro de la Gobernación. ( ... $)^{15}$.

Esta sagaz maniobra revela un evidente uso de las redes caciquiles imperantes. ¿O es que los demócratas de Oviedo, al proponerle a Genaro Alas ir en su candidatura para luego sugerirlo como alcalde, ignoraban que si finalmente lo terminaba siendo era porque disponía de un eficaz valedor en el ex-presidente llanisco? Salta a la vista que no lo desconocían y que, de hecho, se lo pidieron a sabiendas de que el nombramiento tenía visos de prosperar. Los republicanos ovetenses comprendían perfectamente las reglas del juego en el que participaban. Aunque tampoco ha de pasar inadvertido que el propio hostigamiento que sufrían les obligó a buscar soluciones.

mánticos. El papel de Asturias en las insurrecciones contra la Monarquía durante el siglo XIX, Gijón, Zahorí Ediciones, 2011.

13 SÁNCHEZ COLLANTES, Sergio: "Los orígenes de la estrategia mancomunada en el republicanismo español: la democracia por bandera”, Espacio, Tiempo y Forma. Serie V, Historia Contemporánea, 18 (2006), pp. 135-154.

14 Lo demuestra una carta que Palació Valdés le envió a Clarín en 1886, en la que se considera a Genaro "dentro de ese partido". Véase ALAS, Adolfo: Epistolario a Clarín. Menéndez y Pelayo, Unamuno, Palacio Valdés, Madrid, Ediciones Escorial, 1941, pp. 126-127.

15 El Carbayón, 7-V-1883. AHA-FPH, Caja 11.416, Leg. 44, nº 84 (carta fechada en Oviedo el 20-IV1883). 
Ese aprovechamiento de la influencia de terceros podría haberse dado en otros lugares, aunque sería preciso contrastar los testimonios que lo sugieren. Por ejemplo, se ha dicho que el farmacéutico republicano Agustín Bravo llegó a convertirse en alcalde de Cudillero "por su amistad" con el general Julián Suárez Inclán, y que la aceptación del cargo, aunque resultó beneficiosa para la villa, fue "muy censurada" 16 .

También hubo ocasiones en las que se pidió el voto de manera amable. Pero cuando existía una relación desigual de poder e incluso cierta vulnerabilidad en el receptor de la solicitud, ya fuera por razones económicas o laborales, podía derivarse un sentimiento de incomodidad y hasta de coerción evidente. Al respecto, se conserva un magnífico testimonio de Julio Somoza sobre una práctica que no fue excepcional. En 1896 envió una nota a los renteros que habitaban varias casas de su propiedad, al menos dieciséis, recomendándoles la candidatura de un salmeroniano para diputado a Cortes por Gijón:

Amigo Elías: Aunque no pensaba volver a meterme más en cuestión de elecciones, como ahora se presenta don Vicente Innerárity, particular amigo mío, y persona de todo respeto, tendría sumo gusto en que le votasen en las próximas elecciones, cuya indicación la hago en tono amistoso a Vd. y a los demás caseros por si tienen a bien atendérmela seguro de que lo agradeceré ahora y en todo tiempo $(\ldots)^{17}$.

Es necesario recordar, asimismo, que incluso un procesamiento judicial podía terminar con la declaración de inocencia. Por ejemplo, en 1887 el diputado provincial Celestino Rubiera, posibilista, fue suspendido durante un tiempo junto con otro, "como presuntos culpables de coacciones, amenazas y abusos electorales". Pero tras unas semanas, volvió a ocupar su escaño sin aparentes consecuencias. Y al federal Rafael Calzada (padre) llegó a abrírsele una causa "por cuestiones electorales", pero la Audiencia lo absolvió, y la prensa republicana culpó de todo lo sucedido precisamente al caciquismo ${ }^{18}$.

En torno al cambio de siglo, los adversarios de los republicanos siguieron denunciando irregularidades y manejos en los que presuntamente habrían estado implicados. Certificar su autenticidad no es fácil, pero debe constar su existencia. Manuel Vigil Montoto, por ejemplo, vertió en sus memorias unas cuantas acusaciones. De acuerdo con su versión, en las elecciones municipales de 1895 el candidato socialista debía haber obtenido 70 votos y sólo cosechó 16 en una mesa de Oviedo presidida por un republicano. También aseguró que en el mismo concejo, en las de diputados a Cortes de 1901, permanecieron cerrados varios colegios rurales que después "figuraron a favor de los monárquicos y republicanos aliados (...) a gusto de los muñidores de los oligarcas". Este dirigente socialista, que primero había militado en

16 CABAL, Melquíades: Farmacéuticos asturianos. Historia, curiosidades, anécdotas, Oviedo, IDEA, 1982, p. 133.

17 Citada en GUZMÁN SANCHO, Agustín: Biografía de Don Julio Somoza y García-Sala, Fundación Foro Jovellanos, Gijón, 2001, p. 185. El autor no precisa la data de la carta, pero fue el año en que Innerárity concurrió a las elecciones, aunque luego retirase su candidatura (La Época, Madrid, 25-III-1896).

18 AHA-FDP, Libro de Actas, 1887, p. 77 v. (sesión del 16 de mayo). Se anuncia el fin de la suspensión en El Carbayón, Oviedo, 26-VII-1887. Las Dominicales del Libre Pensamiento, Madrid, 14-I-1888. La República, Madrid, 18-I-1888. 
el federalismo, reprobó igualmente que en las municipales de dicho año, a las que se presentaron los monárquicos y los republicanos "en santa coyunda electoral", los socialistas exigieron un recuento y toparon con "un presidente de mesa, republicano federal, por más señas, (que) se negó". Por último, Vigil escribió que, ya en el marco de la conjunción republicano-socialista de 1909, figuró en la candidatura junto a un reformista desleal y trapacero: "pagaba los votos a dos pesetas a los electores que me borraban a mí de la candidatura"19.

Junto con todas las cuestiones señaladas hasta aquí, es importante no descuidar otro fenómeno soslayado con demasiada frecuencia: el de los republicanos que por amistad, deuda contraída o el motivo que fuera dieron su voto a una candidatura monárquica aun teniendo la posibilidad de emitirlo a favor de una republicana. Lo hizo, por ejemplo, el médico Octavio Bellmunt en la década de 1880, apenas un lustro antes de convertirse en dirigente del Partido Republicano Progresista de Gijón. Y él mismo lo confesó, al tratar de defenderse de las acusaciones que le dirigieron otros correligionarios:

(...) En vista de mis desengaños (...), y no estando constituido en esta localidad el Comité democrático, del cual hubiera formado parte, no vi compromiso ninguno en dar mi voto a cualquier amigo, y habiéndomelo pedido en aquel entonces D. Antonino Rodríguez San Pedro, le dije que sí; pero de eso, a que yo le hubiera ofrecido, hay mucha diferencia (...).

Más tarde, otros amigos me hablan para que lo diese al candidato D. Hilario Nava y Caveda, y por último, el Sr. D. Eduardo Marina me dijo vería con gusto votase su candidatura para Diputado provincial, habiéndolo hecho y trabajado en su favor, de lo cual no tengo que avergonzarme ni arrepentirme. $(\ldots)^{20}$.

\section{El uso habitual de las recomendaciones}

Quienes profesaban ideas republicanas no fueron extraños a las prácticas y los hábitos característicos de la época en que vivieron. Uno de los ejemplos más gráficos de ello posiblemente se tenga en las en las omnipresentes recomendaciones. Moreno Luzón ha subrayado que se trató de un fenómeno común en España y los países vecinos, donde llegó a convertirse en "un salvoconducto imprescindible para moverse por el mundo", singularmente quienes tenían que dejar el estrecho círculo local. En cierto modo, el hecho de que los "republicanos más dóciles" se beneficiaran de una pequeña fracción de las prebendas del Estado contribuía a la estabilidad del régimen ${ }^{21}$.

19 VIGIL MONTOTO, Manuel: Recuerdos de un octogenario, Editorial Pablo Iglesias, Madrid, 1992, pp. $67,159,168$ y 257. Fuera del ámbito electoral, también sostiene que hubo "influencias en los juzgados" para que no se detuviera a Rafael Arriba, un obrero federal que en 1902, durante el VI Congreso Nacional del partido, apuñaló por la espalda al delegado por Avilés, Enrique Fernández. Vigil sugiere que se hizo a la espera de que el herido saliera del hospital, “para aminorar la pena que pudiera corresponderle". Los motivos de la agresión no están claros, aunque Rafael había sido expulsado de una sesión abierta por alterar el orden (p. 196).

20 Gijón, Gijón, 23-X-1884.

21 MORENO LUZÓN, Javier: "Teoría del clientelismo y estudio de la política caciquil”, Revista de Estudios Politicos, 89 (1995), pp. 209 y 218-219. 
La correspondencia privada vuelve a ser un laboratorio soberbio para documentar esta práctica en los republicanos. Siendo Posada Herrera presidente del Congreso, por ejemplo, recibió una misiva de Emilio Castelar redactada en los siguientes términos:

“(...) Me intereso vivamente por don José Orejón, persona de una honradez a toda prueba y de condiciones excelentes de carácter. Pretende obtener una plaza de ujier del Congreso, y yo me daría por contento, si viese realizadas sus aspiraciones. (...)”.

Se trataba de algo habitual y continuaría siéndolo. El gaditano le remitió unas cuantas epístolas similares a su "amigo" José María Celleruelo, natural del municipio de Siero. Antes de convertirse en diputado y jefe del republicanismo posibilista asturiano, cuando en 1873 desempeñaba el cargo de gobernador civil de Alicante, recibió varias misivas de las que bastan un par de extractos para comprender el tono: "le recomiendo el dador mi amigo Don Camilo Pérez Pastor, antiguo republicano de esa provincia. Haga cuanto pueda (...)"; "el Sr. Fernández, diputado por esa provincia es amigo mío. Se lo recomiendo eficazmente (...)". En distintos momentos, el tribuno le pidió asimismo a Celleruelo su voto para tal o cual iniciativa:

Mucho le agradeceré que vote en las secciones del viernes (...) para la Comisión que ha de dar dictamen sobre el ferrocarril de Algeciras (...) el nombre que le adjunto, favor al cual quedará muy obligado su amigo q. b. s. m. E. Castelar ${ }^{22}$.

El fenómeno excedió la amistad política, ya que representaba un ingrediente más de los muchos que componían esa intrincada maraña de relaciones, favores y contraprestaciones. Sirva para ilustrarlo la protección y las atenciones que Castelar, previa recomendación de Protasio González Solís, le brindó a Juan de Llano Ponte cuando se trasladó a Madrid. Los contactos privilegiados implicaban facilidades que también reconoció Rafael Fernández Calzada, quien las disfrutó en el Madrid del Sexenio. Entonces, su vida de estudiante se hizo muy ventajosa y confortable por el amparo del autor de Las Nacionalidades, hasta el punto de ser elegido con apenas 19 años representante de Asturias para una asamblea nacional del Partido Federal: "No hay para qué decir que en aquellas mis idas y venidas, el ser pasante de Pi y Margall, me franqueaba todas las puertas y me atraía muchas buenas voluntades" ${ }^{23}$.

Por lo demás, las recomendaciones no constituían meras sugerencias inocentes. Moreno Luzón ha explicado cómo las clientelas políticas afectaron especialmente al terreno de la Administración. Según una concepción patrimonial de la función pública, los ascensos y la provisión de puestos se verificaban habitualmente "por la aplicación de criterios particularistas como el de la amistad política, el parentesco o el paisanaje, y no por la valoración de sus méritos y capacidad para desempeñar un

22 AHA-FPH, Caja 11.415, Leg. 43, nº 62 (carta de E. Castelar a J. Posada Herrera, fechada el 6-X-1882). AHA-FCC, Caja 9.861/32 (cartas de E. Castelar a J. M. Celleruelo fechadas en Madrid (salvo la última, s. 1.], el 14-III-1873, 17-III-1873 y 25-VI-1891).

23 La misiva de Castelar se reproduce en GONZÁLEZ SOLÍS, Protasio: Memorias Asturianas, Madrid, Tip. de Diego Pacheco Latorre, 1889, p. XLVIII. FERNÁNDEZ CALZADA, Rafael: Cincuenta años de América, tomo I, Buenos Aires, Librería y Casa Editora de Jesús Menéndez, 1926, pp. 92-93. 
trabajo u otro". De este modo, "se alimentaba la rueda de favores". Muchas recomendaciones traslucían una clara inconsecuencia política desde el momento en que, como ha señalado Suárez Cortina, el ideal meritocrático constituía uno de los ejes del republicanismo, íntimamente ligado a la universalización del derecho a la educación, pues "convertía la sociedad burguesa en una realidad abierta al esfuerzo individual y al mérito" 24 .

Más aún, el hecho de recomendar no se limitaba a ser una contradicción inocua si un tercero salía perjudicado. A Posada Herrera, por ejemplo, le escribió César Argüelles Piedra, uno de los pioneros de la Unión Democrática de Oviedo, rogándole su influencia para que lo nombrasen juez municipal, pero explicitando su deseo de que otro candidato no lo fuera por razones ideológicas:

(...) es costumbre que cada partido nombre a individuos a él afiliados, y yo no habría de tener la pretensión de que hicieran a mi favor una excepción, por más que todos saben que no he distinguido de política cuando se trataba de administrar justicia.

Hoy es otra cosa: el señor Ribero es un carlista muy conocido. ¿Puedo dudar yo de que entre un carlista y yo elija un Gobierno liberal al carlista?

No debiera dudarlo, y en efecto, no lo dudo, porque sé que él habrá de ser el preferido, apoyado como lo está por Alejandro Pidal.

Esto me obliga a molestarle a usted para suplicarle se interese a favor de mi nombramiento, pero sólo en el caso de que el señor Ribero sea el único vencido (...): que si bien deseo y me conviene el cargo de juez municipal, deseo mucho más, como lo desean otros muchos, que me han obligado a presentarme, que no sea nombrado el señor Ribero ${ }^{25}$.

Algunas recomendaciones, en fin, podían resultar especialmente dañinas, como una que le relató Joaquín $\mathrm{M}^{\mathrm{a}}$ Posada Herrera a su hermano. De acuerdo con la versión de su epístola, el republicano castelarino José María Celleruelo había provocado la cesantía de un empleado que llevaba trabajando en correos once años, fatalidad que además le sobrevino cuando tenía varias bocas que alimentar:

(...) Parece ser que el nuevo nombrado es un pimpollo de primavera, agente de negocios en elecciones por dicho Sr. Celleruelo. Vivía con su padre, escribano de Mieres cuyo archivo produce lo bastante para vivir aquel rapacín único hijo (...). En la idea que tengo de Celleruelo, me parece que al saber el daño que hacía, si quería colocar a su ahijado, pudo buscar otros destinos. Se deja cesante al indicado padre de familia, cuando los que quedan no necesitaban del empleo que hoy tienen en correos por las circunstancias particulares y desahogadas de sus familias ${ }^{26}$.

24 MORENO LUZÓN, Javier: "El poder...”, p. 186. SUÁREZ CORTINA, Manuel: "Republicanismo y nuevo liberalismo en la España del novecientos”, en Manuel SUÁREZ CORTINA (ed.): Las máscaras de la libertad. El liberalismo español, 1808-1950, Madrid, Marcial Pons, 2003, p. 345.

25 AHA-FPH, Caja 11.417, Leg. 45, n⿳2 28 (carta de Argüelles Piedra a Posada Herrea, fechada en Oviedo el 8-VI-1883; la cursiva es nuestra). El remitente matiza que si hubiera otro candidato "de la situación" no tendría esa pretensión.

26 AHA-FPH, Caja 11.413, Leg. 41, nº 77 (carta de Joaquín Ma Posada Herrera a su hermano José, fechada en Oviedo el 13-XII-1881). 
Huelga decir que las recomendaciones no se limitaron al terreno laboral. Ya hemos visto su empleo en los comicios. Al escribirle una carta a Posada Herrera para recabar su patrocinio, el federal Vicente Caso no ambicionaba sino convertirse en su recomendado. Entre sugerir a un aspirante para cubrir un puesto y hacerlo lo mismo con una candidatura, mediatizando con ello el sufragio, había una delgada línea muy fácil de cruzar. De hecho, ni se discernía: era una recomendación más.

Y esta vía, desde luego, funcionó sistemáticamente con los destinos y nombramientos que no resultaban de las urnas, sino de la designación. Celleruelo también la ensayó para lograr que un viejo correligionario se hiciera con una de las senadurías vitalicias que estaban en juego en 1903. En esta ocasión, le dirigió una carta a Antonio Maura: "ruégole y por ello le quedaré agradecidísimo, que apoye, para una de las plazas que se concedan a los liberales, al antiguo y consecuente posibilista D. Ramón Cepeda"27.

\section{La base clientelar de los triunfos de José María Celleruelo}

Para ilustrar la manifestación asturiana más evidente de un caciquismo que pudiera llamarse republicano, hay que detenerse en una figura ya mencionada: José María Celleruelo (1839-1911). Este sierense, amigo de Emilio Castelar desde los tiempos de la República y luego director de El Globo, se presentó, sin éxito, a las elecciones a Cortes de 1879. Entonces fue objeto de diversas calumnias, como las que decían que aspiraba a "destruir las Iglesias y concluir con el culto católico". Paralelamente, sus votantes de Pola de Lena denunciaron haber sufrido coacciones. En adelante, sin embargo, parece que se volvieron las tornas y las acusaciones de cometer irregularidades se dirigirán contra él y sus partidarios ${ }^{28}$.

Con el precedente de haber desempeñado varios cargos de gobernador civil bajo la República del 73, el ascenso imparable de Celleruelo no se produjo hasta los años ochenta. En las elecciones a Cortes de 1881 logró el acta de diputado por Lérida, y en abril de 1884 resultó elegido por Oviedo, representación que conseguiría ya de forma ininterrumpida hasta su muerte, un total de once veces, aunque en los noventa empezó a concurrir por el Partido Liberal ${ }^{29}$. Pues bien, justo unos meses antes del inicio de tan dilatada carrera parlamentaria, hubo en Asturias visitas y reuniones elocuentes que sin duda no fueron casuales.

En julio de 1883 la prensa regional informó la llegada de Emilio Castelar a Oviedo, en compañía de Alejandro Pidal, con el objeto de "pasar una temporada en Somió" ${ }^{30}$. No es un detalle menor, en vísperas del ingreso de la Unión Católica en el Partido

27 AHFAM-FAMM, Caja 28, carp. 7 (carta de J. M. Celleruelo a Antonio Maura, fechada el 11-IV-1903).

28 LANA ARIAS, Manuel: Elecciones..., pp. 98-99.

29 SUÁREZ, Constantino: Escritores y artistas asturianos. Índice bio-bibliográfico, tomo II, Madrid, Imp. Sáez Hermanos, 1936, p. 414.

30 El Carbayón, Oviedo, 3-VII-1883. El Comercio, Gijón, 4-VII-1883. Debo rectificar aquí un error que contiene mi tesis doctoral y que reproduce un artículo que adelantó parte de sus resultados: no hubo lazo familiar alguno entre Concepción Castelar y el marqués de Pidal (Luis Pidal). El origen de esta equivocación se halla en la noticia inexacta que difundieron varios periódicos en enero de 1889, al cruzar informaciones de la muerte de la hermana de Castelar y la de la marquesa de Pidal, ocurridas en horas próximas. El lapsus figura 
Conservador y del triunfo electoral de Celleruelo, que el líder posibilista disfrutara de unos días de reposo en el centro estratégico de la maquinaria pidalina, en la quinta desde la que don Alejandro gestionaba cada verano su entramado caciquil. Según informó en los noventa el cónsul británico en Gijón, Pidal estaba "en buenas relaciones con los mayores propietarios y principalmente con los patronos"; y esa influencia superaba los límites provinciales "gracias a sus conexiones con el mundo católico" ${ }^{1}$.

A su vez, Emilio Castelar mantuvo con Cánovas del Castillo una "amistad a toda prueba", según ha explicado Carlos Seco Serrano, en la que no faltó su presencia en almuerzos y veladas. El jefe del republicanismo conservador, pues, se hallaba en una situación idónea para recompensar a Celleruelo por sus favores y servicios. En tal posición, ¿qué necesidad había de organizar mítines durante su hermética estancia para apoyar la candidatura de su lugarteniente sierense? La opinión pública importaba poco. Es impensable que Pi y Margall hubiera pasado varios días en Gijón sin arengar a sus huestes y en medio de tanto secretismo. Ciertamente, no todos los líderes republicanos actuaron de la misma forma. En este sentido, Dardé ha subrayado que hombres como Pi, Salmerón y Ruiz Zorrilla "fueron siempre ejemplos cabales de honestidad pública, pero no así Castelar, cuya fama llegó a estar seriamente en entredicho". Ocurrió incluso en sus propias filas, ya que el director de un rotativo posibilista le confesó una vez a Ramón y Cajal: "aquí nadie juega completamente limpio, ni siquiera nuestro jefe que, por vivir de su trabajo, pasa por ser de los menos contaminados por las flaquezas del compadrazgo y del favoritismo" 32 .

Celleruelo no gozó de mejor fama en lo tocante a su relación con las prácticas caciquiles y el abuso de la influencia. Los dardos que el semanario zorrillista $L a$ Verdad lanzó contra "los pidalino-celleruelistas" tenían su explicación, lo mismo que dicho léxico, justificado por lo común de esas alianzas heteróclitas. Un inequívoco telón de fondo motivaba los lamentos de ese periódico local acerca del Ayuntamiento de Oviedo: "Pidal y Celleruelo abrazados íntimamente para disponer ab irato de nuestros destinos ahogando aquí las legítimas expansiones de los liberales y de los demócratas". Se referían al "candidato que para la Alcaldía tenían (acordado) Pidal y Celleruelo". No en vano, fue normal que cada verano, al suspenderse las sesiones de las Cortes, ambos regresaran al norte en el mismo tren. A la luz de todo ello, se entienden mejor las crípticas alusiones de Víctor Polledo, cuando se refirió al sierense como Jano y sus tres caras políticas, e ironizó con su físico:

en SÁNCHEZ COLLANTES, Sergio: "Una visión global sobre el republicanismo en Asturias durante el siglo XIX", Historia Contemporánea, 38 (2009), p. 204; así como "Republicanismos y tradición democrática en Asturias en el siglo XIX. Ramificaciones y protagonistas de la heterodoxia”, Tesis doctoral, Universidad de Oviedo, 2011, pp. 415-416 y 610.

31 VARELA ORTEGA, José y DARDÉ MORALES, Carlos: "Las claves de la política oficial: jefes, familias y clientelas", en Manuel ESPADAS BURGOS (coord.): La época ..., pp. 104-105. LÓPEZ OLIVEROS, Antonio: Asturias en el resurgimiento español, Gijón, Silverio Cañada, 1989, pp. 45-46: “(...] Por los veranos (Pidal] aparecía en Asturias, y en su quinta de Somió (Gijón) establecía el cuartel general, adonde acudían a recibir órdenes los edecanes, que se distribuían en concejos o distritos electorales el comando de la provincia. Así gobernaba Pidal su feudo en Asturias: por delegación en caciques de menor cuantía que hacían más odioso, más depredatorio, más insoportable y más inhumano el sistema. (...]”.

32 SECO SERRANO, Carlos: De los tiempos de Cánovas, Madrid, Real Academia de la Historia, 2004, p. 140. DARDÉ, Carlos: “La larga...”, p. 131. 
"el rostro fresco (...) y retocado con los arreboles afeites y cosméticos que busca(ba) y solicita(ba) de la gran perfumería establecida en Somió (casa de campo de Pidal y Mon), y de su sucursal acreditada en Valdesoto (posesión del marqués de Canillejas)"33.

Los testimonios en ese sentido podrían multiplicarse. Adolfo Posada escribió que durante su primera estancia en Madrid, hacia 1878, su tío Manuel Pedregal y él cenaron en cierta ocasión con "un futuro gran cacique astur, entonces algo periodista y, esto aparte, extraordinariamente feo -Celleruelo". También Clarín, en sus críticas al posibilismo de los inicios de la Restauración, deslizó mordaces alusiones cuyo doble sentido hay que tener presente. Así cuando manifestaba: "nuestro amigo Celleruelo deberá la votación respetable que obtenga (...) a sus amigos particulares, no a sus correligionarios, porque no los tiene (...); ni al partido democrático, que no va a las urnas". O, en la misma línea: "venza o no el Sr. Celleruelo, (...) a buen seguro que los votos que tenga no ha de deberlos a su posibilismo, sino a las buenas relaciones de que disfruta en el país". Lo que no deja lugar a dudas, es que eligiera para terminar un artículo el sarcástico colofón: "Pero ¿qué tiene que ver la influencia moral con los posibilistas? Diga Vd., señor director, ¿tiene algo que ver?"34.

En los periódicos madrileños también se filtraron referencias elocuentes. En 1891, un corresponsal de El País definió Asturias como "una especie de granjería que explota(ba)n a su favor cuatro imbéciles erigidos en caciques por obra y gracia de D. Alejandro", tachando a Celleruelo de "su aliado y compinche en las cuestiones de política local". Un lustro después, una semblanza del sierense afirmaba de su relación con Pidal: "son como primos políticos que se entienden y se guiñan el ojo en asuntos de casa"; y más elocuentemente: "en su distrito se multiplican los votos como el pan y los peces del Evangelio; y todos aplauden la habilidad del secretario escrutador". Todavía en 1905, en Las Dominicales del Libre Pensamiento sentenciaban: "Melquíades Álvarez es hoy instrumento del Sr. Celleruelo, y ambos en común servidores de Pidal". Y al año siguiente, en unas declaraciones sobre "la guerra al caciquismo", el zorrillista Fernández Llana habló de lo mismo en una entrevista: "en esto no entendíamos de colores y medíamos por un nivel a Pidal, los Inclanes, Toreno, Celleruelo, Lema, Canillejas, Mon (...)". La prensa conservadora realizó similares observaciones, como las de su corresponsal en Gijón en 1887:

El distrito de Pola de Siero, que representa en las Cortes el Sr. Celleruelo, es una especie de feudo que el Gobierno concede a este señor para no hacerlo menos que a su jefe, Sr. Castelar, en Huesca; dando esto por resultado que los valiosos elementos con que los partidos conservador y liberal allí cuentan, capitaneados por el Sr. Marqués de Canillejas y Uría respectivamente, se vean en situación crítica $(\ldots)^{35}$.

33 La Verdad, Oviedo, 5, 12 y 26-I-1890. El Comercio, Gijón, 31-VII-1889. "Recuerdos locales”, en El Correo de Asturias, Oviedo, 15 y 17-I-1895. Las acotaciones entre corchetes relativas a Somió y Valdesoto (parroquia de Siero) figuran anotadas al pie en el texto original.

34 POSADA, Adolfo: Fragmentos de mis memorias, Oviedo, Universidad de Oviedo, 1983, p. 92. La Unión, Madrid, 2 y 13-IV-1879.

35 El País, Madrid, 14-III-1891. Almanaque Asturiano de El Carbayón para 1895, Oviedo, Mases, 1987 ( $1^{\mathrm{a}}$ ed. 1894), p. 62. Las Dominicales del Libre Pensamiento, Madrid, 22-VII-1905. "Una intervieu. Los republicanos de Oviedo", en El Noroeste, Gijón, 6-I-1906. La Época, Madrid, 2-IX-1887. 
¿Qué hubo de verdad en las afirmaciones de Posada, Clarín, Polledo y numerosos periódicos? Excusa decir que tales manejos no solían hacerse públicos y sus beneficiados los negaban terminantemente. Un magnífico ejemplo se tiene en el posibilista Eleuterio Maisonnave, diputado por Alicante gracias a la recomendación ministerial. Cuando se habló del asunto en las Cortes, replicó tajante: "Eso no es verdad". Sin embargo, era demasiado evidente, aunque, como manifestó un diputado liberal, se hubiera verificado "en la forma delicada y digna en que los gobiernos recom(endab) an estas candidaturas" 36 .

En lo tocante a Asturias, la correspondencia particular de Posada Herrera ofrece referencias esclarecedoras, a falta de materiales más valiosos para ilustrar este asunto; ni siquiera entre los propios fondos de la Casa Celleruelo, alojados en el AHA desde hace unos diez años. Sobresale un testimonio de junio de 1883, en el que Pedro López Grado encuadraba al sierense dentro de la flor y nata del caciquismo regional. En su misiva empleaba el gráfico sintagma "republicanismo vergonzante". Decía la carta:

Jamás, en ninguna época, jamás repito ha estado esta provincia en un estado tan lastimoso y deplorable, entregada de una manera sin tregua, sin defensa y sin leyes para los oprimidos, al capricho y al poder usurpador representado por Alejandro Pidal el de las honradas masas carlistas, por Celleruelo, viva representación de los republicanos posibilistas y por los conservadores y moderados representados por los Gastañagas y Torenos, contubernio horrible, apoyado, protegido por toda clase de arbitrariedades y atropellos, nunca experimentados en este país y al parecer a gusto y contento, alegría y placer del gobierno que se llama constitucional, abandonando y persiguiendo a los que (...) no se someten humildemente como siervos a la tiranía sin límites de los que ostentan la bandera que tremolan con cinismo llevando en ella y en sus pliegues en letras de oro carlismo, moderantismo y republicanismo vergonzante ${ }^{37}$.

Precisamente del concejo de Siero, feudo personal del entonces director del $E l$ Globo, se quejó también López Grado. Reconocía que "no contaba que Pidal se prostituyese hasta ese punto" y calificaba al diputado provincial por Infiesto, Eguívar, como "pidalista acérrimo y amigo de Celleruelo". Lo denunció en los siguientes términos:

(...) es horrible lo que aquí sucede. Cartas por todas las parroquias de D. Alejandro Pidal y del republicano Celleruelo. República y carlismo y el Gobernador esbirro, criado y esclavo de estos personajes. Los propietarios de este Concejo nos hemos retraído en la elección Municipal última y aun así este singular matrimonio que antes se hacían una guerra cruel, a pesar de tantos amaños y tropelías, no han conseguido el triunfo y eso que el Gobernador descartó por miles a los electores, como ha sucedido en todas

36 GUTIÉRREZ LLORET, Rosa Ana: El republicanismo en Alicante durante la Restauración, 18751895, Alicante, Ayuntamiento, 1989, p. 182.

37 AHA-FPH, Caja 11.416, Leg. 44, no 57 (carta de Pedro López Grado a Posada Herrera, fechada en Madrid, el 6-VI-1883). Seguía diciendo: "El sufragio electoral secuestrado por completo a los liberales; los jueces municipales nombrados y dependientes del caciquismo imperante, los destinos y la administración civil, política, judicial y militar todo, todo a las órdenes de esta odiosa trilogía, viva encarnación de la demagogia blanca, del socialismo vergonzante y la anarquía de elementos tan extremadamente heterogéneos que sólo los agrupa miras y ambiciones bastardas por dominar a este desventurado país. (...]”. 
partes. Como dije antes, quieren que todos los Jueces Municipales sean sus esclavos y verdugos de los que consideran sus enemigos. Aquí, Siero, quieren que sea elegido Juez Municipal D. Perfecto Argüelles que por su mala conducta, pésimos antecedentes y detestable administración como Alcalde que fue, habiendo sido elegido Juez (...) Alejandro Pidal consiguió del Ministro de Gracia y Justicia Aurioles que por una R. O. se anulase dicho nombramiento después de estar nombrado con todas las formas legales (...). Pues bien, Pidal cambia, el carlista se convierte en republicano, se niega a sí mismo, adora lo que ayer quemó, como el Rey Sicambro, y por servir a Celleruelo le apoya con decisión y entusiasmo. ¿Qué calamidad para este país Pidal y sus nuevos e inverosímiles amigos! ${ }^{38}$

A las dos semanas, López Grado volvió a dirigirse a Posada Herrera, lamentando que las recomendaciones del llanisco hubieran sido ignoradas: "Hervás me ha dicho que había nombrado todos los Jueces Municipales que le habían designado los Pidales, Torenos, Celleruelos y algunos carlistas como Revillagigedo". Hablaba de la "odiosa trilogía" y no fue la última ocasión en que se quejó de sus maniobras: "aquí los liberales de toda la vida vivimos tiranizados y esclavizados y en completo y absoluto dominio los carlistas, posibilistas y conservadores". Ni era la primera vez que trataba con el llanisco la cuestión de los jueces municipales, abordada ya en 1881: "El tal Ason es republicano, amigo íntimo de Celleruelo y quiere la influencia que le da el juzgado para trabajar por los republicanos" 39 .

Del peso que Celleruelo tenía entonces, dio noticia igualmente Faustino Valledor, al trazarle a Posada Herrera un balance de la situación en vísperas de aquellas elecciones a Cortes y hablarle del "apoyo que el Gobierno da(ba) a Celleruelo concediéndole destinos" ("más que a ninguno de nosotros", apostillaba). También el marqués de Muros, al afirmar que San Miguel y el sierense tenían "entrada en los Ministerios". Allí, por cierto, recomendación mediante, les procuró trabajo a muchos convecinos, según el testimonio de Fausto Vigil: "Su casa de Madrid -y no se diga por los veranos la de La Carrera- era tan frecuentada por sus paisanos que alguien la llamaba Consulado de Siero, con gran satisfacción del bueno de Celleruelo". Dejó escrito el cronista local:

(...) fueron muy numerosos los jóvenes de Siero, sobre todo de La Carrera, que encontraron colocación, por el señor Celleruelo alcanzada, en el palacio de las Cortes, en donde llegaron a estar en mayoría entre todo el personal de la casa. Ya los diputados daban por descontado que en cuanto vacaba una de esas plazas se avecindaba en

38 AHA-FPH, Caja 11.416, Leg. 44, nº 57 (carta de Pedro López Grado a J. Posada Herrera, fechada en Madrid, el 6-VI-1883). La necrológica de Perfecto Argüelles Prieto, fallecido cuando era alcalde de Pola de Siero, recuerda su evolución desde posturas republicanas a otras dinásticas (véase en El Avance, Gijón, 2-III1900).

39 AHA-FPH, Caja 11.416, Leg. 44, nº 57 (cartas de Pedro López Grado a Posada Herrera, fechadas en Agüeria, el 22-VI y 21-VII-1883); Caja 11.412, Leg. 40, nº 91 (ídem, fechada en Agüeria, el 7-VI-1881). En la última carta se aprecia cómo, sólo dos años antes, a López Grado no le molestaba en absoluto pactar con un conservador si le beneficiaba: “(...] en Gijón, donde mi querido amigo Revillagigedo tiene una influencia decisiva, he podido conseguir que apoye al candidato del Gobierno". 
Madrid un paisano de Celleruelo. ¡Y era de ver la satisfacción de D. José cuando oía a sus compañeros aquellos comentarios! ${ }^{40}$.

La influencia del Gobierno ya se puso de manifiesto en las elecciones a Cortes en las que Celleruelo obtuvo su primer escaño por Oviedo. Con dos meses de antelación, Fermín Canella pronosticó certeramente el nombre de los tres diputados triunfantes para los comicios de abril de 1884, evidenciando las buenas relaciones del sierense con el Ministerio de la Gobernación conservador: "La circunscripción (Oviedo, Lena y Laviana) votará oficialmente a Luis Pidal, Camposagrado y a Celleruelo, que se dice muy unido con el ministro" 41.

Sobre cómo manejaba Celleruelo sus propios negocios electorales, fuera de lo que se urdía en Gobernación, algo puede decirse. Por lo pronto, los banquetes políticos desempeñaron un papel neurálgico, alimentando una forma de sociabilidad que robustecía nexos y lealtades. Cada verano se celebraba puntualmente un ágape en su honor: "este obsequio dispuesto por los amigos políticos y particulares del Diputado posibilista, como todos los años lo vienen haciendo, es una prueba más de la gratitud profunda que el concejo de Siero abriga hacia el Sr. Celleruelo". Y sus connotaciones políticas son evidentes, por mucho que el cronista de turno dijera lo contrario: "sin revestir carácter político el banquete, tenía sin embargo el distintivo indudable de componerse de personas que se sentían unidas por la simpatía que inspiran los ideales del credo posibilista". Ahora bien, esa representación del municipio era demasiado selecta, a juzgar por el menú y los escogidos vinos que se servían. Entre otras viandas, los celleruelistas degustaron en un mismo convite lengua trufada, filetes de vaca con champiñones, jamón en dulce a la andaluza y salmón a la tártara. La puesta en escena y el ditirámbico agasajo revestía todas las peculiaridades de los de su clase, incluidas las coplas de agradecimiento al que podríamos llamar evergetismo caciquil: "El concejo de Siero / ha progresado / desde que Celleruelo / es diputado" 42.

Entre los reunidos en dichos actos se hallaban los agentes electorales e intermediarios de Celleruelo durante sus largas estancias en Madrid. Uno de los asiduos comensales, Gregorio Vigil Escalera, corresponsal del Banco de España en Pola de Siero, fue a quien Celleruelo dirigió una carta nada más que tuvo noticia de la defección de ciertos apoyos estratégicos en su maquinaria. Copia autógrafa del original, constituye un documento excepcional que ratifica que Celleruelo llevó la batuta en Siero durante más de veinte años. Aunque data de 1903, cuando ya pertenecía al Partido Liberal, los entresijos y bases de su influencia no habrían variado hasta ese momento, sino que tan sólo debieron de reajustarse (seguramente en su evolución al monarquismo arrastró a buena parte de su clientela). La epístola también demuestra que a principios del siglo XX se vivió el canto del cisne del celleruelismo, amenazado por la deslealtad

40 AHA-FPH, Caja 11.412, Leg. 40, no 98 (carta de Faustino Valledor a J. Posada Herrera, fechada en Oviedo el 10-VII-1881); nº 93 (carta del marqués de Muros a J. Posada Herrera, fechada en Madrid el 30IV-1881). VIGIL ÁLVAREZ, Fausto: Notas para una bio-bibliografía de Siero (Asturias), Santander, Aldus, 1949, pp. 18-19. Recordemos que La Carrera es la parroquia natal de Celleruelo.

41 AHA-FPH, Caja 11.419, Leg. 47, nº 78 (carta de Fermín Canella a Posada Herrera, fechada en Oviedo el 17-II-1884; la cursiva es nuestra).

42 El Carbayón, Oviedo, 4-VIII-1883, 22-VIII-1888 y 25-IX-1890. 
de lo más granado de sus respaldos. El sierense escribió una misiva a Gregorio nada más recibir otra de su cuñado Pepe (José Díaz Faes):

(...) Todo cuanto en ella me dice, me lo habían escrito hacía varios días desde Oviedo y no sólo no quise creerlo, sino que me reí de los que tales cosas me contaban (...).

Y lo consideraba imposible porque haciendo examen de conciencia, no encuentro en mi memoria acto alguno que justifique (...) que amigos míos de toda la vida, a los cuales jamás hice un agravio y a los que si no serví más fue porque no estuvo en manos mías el hacerlo, se conjuren contra mí, y sin decirme nada, como si yo les hubiera hecho una ofensa manifiesta e imperdonable, se preparen a combatirme en la próxima lucha electoral. $(\ldots)^{43}$.

Celleruelo reflexionaba, notablemente contrariado, sobre los posibles motivos de la apostasía, procurando recabar una explicación de Gregorio Vigil Escalera: “¿Quiere V. amigo Gorín, decirme con toda lealtad y franqueza, lo que V. sepa?". Luego, en un pasaje crucial, revelaba que seguramente permitió tal autonomía en su cacicazgo que sus principales delegados en él terminaron cambiando de obediencia. De lo contrario, resulta difícil explicar que el abandono de un par de enlaces inquiete tanto a Celleruelo, que pese a todo se muestra desafiante:

(...) La lealtad con que yo he procedido siempre, y la confianza que en mis amigos de Siero yo he depositado, dejándoles árbitros de todo, y evitando toda intervención a Canillejas en ese Concejo, me ponen hoy en malas condiciones para la lucha, y bien creo que puedo ir a ella en ese concejo, atado, o poco menos, de pies y manos, pero así $\mathrm{y}$ todo lucharé y me defenderé con uñas y dientes, aunque tenga el dolor de perturbar la tranquilidad que desde que yo fui diputado goza Siero $(\ldots)^{44}$.

El poleso reconocía hallarse en una situación "muy desfavorable", pero decidido a "luchar a todo trance". De ahí la necesidad de conocer los apoyos que mantenía: "me conviene saberlo para no molestar a quien haya adquirido otros compromisos". También se jactaba de sus servicios al municipio, al cual aseguraba haber librado de las redes de influencia: "conseguir que se administre a su gusto y haga lo que bien le parezca sin atender a imposiciones de caciques". Aunque lo que sucedió realmente es que él mismo había asumido ese rol. Celleruelo llevaba demasiado tiempo en los mentideros oficiales como para que el desmoronamiento de sus apoyos en Siero colapsara su fulgurante carrera parlamentaria. En esos 21 años se había labrado buenas relaciones en otros ámbitos, y no sólo venció en 1903, sino también en 1905 y en 1907. Es más, sólo dejó de ser diputado cuando así lo quiso, como prueba el hecho de que en 1910 declinara el ruego del Presidente del Consejo de Ministros para volver

43 GUTIÉRREZ MAYO, José y ÁLVAREZ URÍA, Gerardo: Guía general de Asturias, Gijón, Compañía Asturiana de Artes Gráficas, 1904, p. 80. AHA-FCC, Caja 9.861/35 (copia autógrafa de la carta que J. M. Celleruelo remitió a Gregorio Vigil Escalera, fechada el 11-I-1903).

44 Ibidem. La cursiva es nuestra. 
a presentarse. En ese momento, se propuso al Rey su nombramiento como senador vitalicio, lo que atestigua sus privilegiados contactos ${ }^{45}$.

\section{Otros republicanos en entredicho}

El celleruelismo no es el único ejemplo de vinculación entre un jefe republicano y las prácticas caciquiles que se documenta en Asturias. Por no hablar de quienes, oriundos de dicha provincia, hicieron carrera en otras regiones. Así el zorrillista gijonés Calixto Rodríguez García, fue diputado por Molina de Aragón (Guadalajara) entre 1891 y 1907 - salvo en 1896-. Olvidado por la historiografía de su tierra natal, era además sobrino del industrial republicano Tomás Zarracina. Dardé ha explicado que, desde su puesto de ingeniero de montes, logró ganarse la confianza de los pueblos, prometiéndoles defender sus derechos en el pleito que mantenían con el duque de Medinaceli sobre la propiedad de los comunales. Arrendó los montes al aristócrata para luego comprarlos y venderlos a la Unión Resinera Española, que él mismo había fundado, de manera que al instalar una fábrica que dio trabajo a los vecinos de la zona consiguió labrarse una regular fortuna personal y una clientela sobre la que ejerció una autoridad paternal ${ }^{46}$.

Varela Ortega ha recordado que también Melquíades Álvarez, elegido diputado por Oviedo en 1898, "tuvo que recurrir a métodos caciquiles". Ocurrió que, habiendo obteniendo miles de votos en las secciones urbanas, su contrincante rellenó como quiso las actas en blanco de las aldeas. Para López Oliveros, de hecho, lo que sucedió andando el tiempo es que Melquíades "remedará a Pidal su caciquismo". Y, según la versión que da en sus memorias el socialista Vigil Montoto, ni el recto Pedregal habría sorteado el desdoro en las elecciones de 1893 para diputados a Cortes:

(...) Se habían entendido republicanos, posibilistas y conservadores, dándose el caso inaudito de que en la Sección establecida en la Casa Consistorial de Pola de Siero, que no contaba en su censo más que con 434 electores, se adjudicaran al señor Pedregal 14.000 votos y un pico; 11.000 y también un pico al señor Celleruelo, y 12.000 votos, con su correspondiente pico, al marqués de Canillejas $(\ldots)^{47}$.

El funcionamiento clientelar de aquella sociedad también explica que el ascendiente de cualquier notable o líder republicano sobre una parte del vecindario fuera

\footnotetext{
45 AHA-FCC, Caja 9.861/31 (notificación fechada el 15-IV-1910).

46 El Liberal, Madrid, 14-XII-1898. El Noroeste, Gijón, 16-XII-1898. DARDÉ, Carlos: "El movimiento...", p. 561.

47 VARELA ORTEGA, José: Los amigos políticos. Partidos, elecciones y caciquismo en la Restauración (1875-1900), Madrid, Marcial Pons, 2001, p. 463. LÓPEZ OLIVEROS, Antonio: Asturias ..., p. 48. Este autor matiza: "No diremos, porque la comparación hecha de un modo absoluto sería injusta, que un caciquismo sustituyó a otro. Con Pidal, el caciquismo político en Asturias se quiebra definitivamente. Lo que se produce a su muerte es una sustitución de personalidades representativas". VIGIL MONTOTO, Manuel: Recuerdos..., p. 50. En cambio, POSADA, Adolfo: Fragmentos ..., op. cit., 1983, p. 261, asegura que Pedregal representó la circunscripción de Oviedo de forma limpia, "luchando siempre contra el aplastante caciquismo de Pidal y con la ingratitud del posibilismo castelarino". En este caso, el número de fuentes que destacan la moralidad de Pedregal es muy superior al de las que dicen lo contrario.
} 
un botín apetecido por otros en determinados momentos. De ahí el interés que mostró el candidato liberal por Infiesto en las elecciones a Cortes de 1881, Bernardino Díaz de Rivera, para conseguir el apoyo del médico piloñés Luis Arroyo, republicano y pariente del diputado del 73 José Arroyo Ortiz. Únicamente se explica por tratarse de una persona influyente que ejercía su "predominio moral" sobre un número significativo de votantes. La correspondencia que mantuvo Díaz de Rivera con Posada Herrera resulta elocuentísima ${ }^{48}$. Martínez Agosti recuerda que, en efecto, el monopolio que el padre de Luis, Ramón Arroyo, había ejercido en el comercio fue la base del predominio de la familia, que extendió sus negocios incluso a Cangas de Onís y otros municipios vecinos. Al aumentar el volumen "de sus especulaciones", en definitiva, creció el de sus bases clientelares:

Había llegado a constituir tal número de relaciones mercantiles en el inmediato Concejo de Caso, que todo él llegó a considerarse obligado a surtirse en su establecimiento, a tomarle ganado en aparcería y a recibir de sus manos numerosos préstamos a pagar en las épocas de la recolección del maíz y de la avellana con estas mismas especies $^{49}$.

Otro supuesto diferente lo hallamos cuando, en lugar de ser el republicano en cuestión una pieza activa en el circuito de las influencias, es decir, quien las detenta sobre un grupo variable, deviene receptor de las ofertas de quienes manejan los resortes. Los nombres de conspicuos demócratas llegaron a sonar en los centros de poder. Así el de Félix Aramburu, como candidato para la Diputación provincial. Entonces, otra vez se puso de manifiesto que nada se podía hacer sin el apoyo del notable de turno:

(...) De regreso pasaremos por Teverga y Quirós, en cuyo concejo visitaremos al rico propietario D. Bernardo Terreros, a quien es preciso rendirle pleito homenaje para tenerlo propicio en la época de elecciones. Llevo ánimos de hablarle de D. Félix de Aramburu, por si le pareciese buen candidato para el distrito de Lena. $(\ldots)^{50}$.

Para el Senado se reprodujeron las mismas prácticas. Son muy ilustrativas, por ejemplo, las negociaciones que hubo entre bambalinas para el nombramiento de los senadores que la Ley electoral de 1877 reservaba a las Sociedades Económicas de

48 En un primer momento, obtener ese respaldo parecía difícil: "Los Arroyo, como republicanos, apoyarán a D. Manuel Pedregal si se presentase, que lo dudan”. Luego se tornó una meta conquistable: “(...] Ayer recibí carta de Infiesto manifestándome que la familia de Arroyo no oculta sus simpatías por mi candidatura, y me añaden que sería muy conveniente que D. Joaquín Fernández Cardín recomendase ahí mi candidatura a D. Luis Arroyo, para que cuando viniese a Infiesto en la primera quincena de mayo la familia acordase apoyarme. Esperan al parecer la venida de Luis para resolver. (...]”. Y finalmente, quedó descartada: “(...] Algunos amigos de Infiesto me escribieron ayer una carta colectiva manifestándome que los Arroyo y Gómez con todos los suyos están con Mendoza (Cortina] (...)". Véase AHA-FPH, Caja 11.412, Leg. 40, nº 82 (cartas de Bernardino Díaz de Rivera, candidato por Infiesto, a J. Posada Herrera, fechadas en Llanes el 23-III, 29-IV y 30-VI-1881).

49 MARTÍNEZ AGOSTI, Nicolás: El perfil de Piloña, Madrid, Imprenta Renacimiento, 1916, pp. 174 176. Como señala el autor, la casa de Arroyo tuvo "gran peso en el campo de la política" y se convirtió en "una palanca electoral de gran resistencia".

50 AHA-FPH, Caja 11.413, Leg. 41, nº 80 (carta del gobernador civil, José María Díaz, a J. Posada Herrera, fechada en Oviedo el 23-VI-1882). 
Amigos del País. En semejante cambalache de favores, influencias y recomendaciones, no faltó la mediación de Emilio Castelar, quien, para que un aspirante lograse el voto de Canella en 1884, solicitó el auxilio de Posada Herrera. El jefe posibilista le comentaba al llanisco:

(...) Dispense que me atreva hoy a molestarle (...). Presentamos con grandes probabilidades de éxito por la Sociedad económica de León para el Senado a nuestro amigo y correligionario Don Antonio Ramos Calderón. El compromisario de Oviedo se llama Don Fermín Canella y Secades, que pertenece a las ideas liberales avanzadas pero que no puede prestarle su apoyo sin la previa y superior anuencia de V., según mis noticias. Nosotros quisiéramos merecer de su bondad que, o bien dejara libre al Sr. Secades la disposición de su voto, o si bien le parece, se interesara por nuestro amigo $(\ldots)^{51}$.

Así que muchos de los jefes de ciertos republicanismos, especialmente - aunque no sólo- del posibilista, no tuvieron empacho a la hora beneficiarse de comportamientos que en su propaganda juzgaban censurables. ¿Idénticos medios para distinto fin? No es tan sencillo. Personajes como Celleruelo podrían incluirse en la nómina de políticos que, según ha explicado José Varela, "estaban sumidos en una creciente contradicción entre sus deseos y logros (...), y las exigencias a que les sometía el sistema como jefes de partido y bandería". Así que no pocas veces, como indica Suárez Cortina, "los republicanos aprovecharon, sin sonrojo, cuantas oportunidades ofrecía el sistema para lograr un acta de diputado". El moscón Valentín Andrés, que había nacido en 1891 y algo conoció de la vida política de la Restauración, dejó escrito en sus memorias que había "caciques de todos los matices y colores: conservadores, liberales, republicanos y socialistas". Las reflexiones que Salvador Canals hizo sobre la provincia de Oviedo en 1900 hablan igualmente de la flaqueza que en ese sentido caracterizó a un subconjunto del republicanismo asturiano:

Si la impaciencia por llegar cómodamente a la posesión sosegada del distrito no hubiese hecho que algunos republicanos templados y todos los liberales de Asturias se fueran rindiendo a la hegemonía del señor Pidal para acatarla, ¿cómo había de ser ella lo que es? ${ }^{52}$

Del posibilismo asturiano representado por Celleruelo se puede hacer una valoración ambivalente, similar a la expresada por Gutiérrez Lloret. De un lado, se convirtió en una especie de oposición consentida, que se integró en el sistema político de la Restauración "legitimándolo, contribuyendo a su consolidación", lo

51 AHA-FPH, Caja 11.412, Leg. 40, $\mathrm{n}^{\circ} 85$ (carta de Emilio Castelar a J. Posada Herrera, fechada en Madrid, el 11-VII-1881).

52 VARELA ORTEGA, José: "Sobre la naturaleza del sistema político de la Restauración", en Guillermo GORTÁZAR (ed.): Nación y Estado en la España liberal, Madrid, Nóesis, 1994, p. 186. SUÁREZ CORTINA, Manuel: "Entre la...", p. 522. ANDRÉS ÁLVAREZ, Valentín: Memorias de medio siglo, Oviedo, Caja de Ahorros de Asturias, 1989, p. 55. CANALS, Salvador: Asturias. Información sobre su presente estado moral y material, Madrid, M. Romero, 1900, p. 140. 
cual también frustraba "cualquier intento de transformación política en un sentido verdaderamente democrático". Pero, de otro lado, eso no debe hacer olvidar una realidad más amplia, la de la marginación del republicanismo sensu lato, que también se manifestó en las elecciones municipales y provinciales, cuyos resultados "nos dan la medida exacta de su subordinación política y de su impotencia frente al sistema" 53 .

Sobre los vínculos de ciertos republicanos con los partidos del turno y su recurso al fraude y a las prácticas caciquiles, Dardé ha llegado a conclusiones que en buena medida resultan válidas para todas las provincias. La más importante es que la sola identificación con la democracia siempre proporcionó al discurso republicano un cariz moralizador, y ciertamente la integridad distinguió a muchos republicanos, pero en la práctica hubo quienes no pudieron o no quisieron sacudirse los vicios imperantes, entre ellos "la corrupción que dominaba en el ambiente político". Y eso que también los discursos contravenidos tenían su valor, porque, aun cuando buscaran los favores y la influencia, como ha señalado Demetrio Castro, los jefes republicanos "aleccionaron incansablemente a sus seguidores con la doctrina de la pureza intangible de los principios" ${ }^{4}$.

Por lo demás, no todos los republicanos actuaron de igual forma. De hecho, la estrecha relación que algunos mantuvieron con las oligarquías fue una de las brechas que los separó irremisiblemente de otros correligionarios. Así se explica, por ejemplo, que durante las elecciones a Cortes de 1881 muchos elementos del Partido Democrático ovetense prefirieran apoyar otras candidaturas antes que la de Celleruelo, algo que ya había sucedido también en $1879^{55}$. Para un sector importante del republicanismo, la moralidad y el honor eran virtudes irrenunciables que había que preservar en nombre de la consecuencia.

\section{Conclusiones}

El caciquismo constituyó un fenómeno de recodos intrincados. La mera participación en el sistema político restauracionista hacía complicado no incurrir en pecados, aun cuando se hiciera para expresar una posición crítica. Y los republicanos de Asturias conocían las reglas del juego. No obstante, hay que subrayar que los diferentes vínculos que se constatan entre republicanos y prácticas caciquiles, como los vistos en estas páginas, se verificaron de forma y en grados muy desiguales. La heterogeneidad de supuestos es notoria y parece obligado introducir matices.

No ha de sorprender que el republicanismo que más utilizó el clientelismo fuera el posibilista, igual que sucedió en otras provincias. Ante la nueva legalidad estrenada en 1875, sus líderes mantuvieron en general una disposición cuando menos aquiescente, docilidad que fue recompensada con escaños, puestos y destinos. En

53 GUTIÉRREZ LLORET, Rosa Ana: El republicanismo..., p. 184.

54 DARDÉ, Carlos: "La larga...", pp. 132-135. CASTRO, Demetrio: "Republicanismo español: de la revolución al fin de siècle. Mismo vino, mismos odres”, en Ángeles LARIO (ed.): Monarquía y República en la España contemporánea, Madrid, Biblioteca Nueva, 2007, p. 60.

55 El Carbayón, Oviedo, 18-VIII-1881. 
Asturias, la manifestación más perfecta de ese fenómeno se halla en el celleruelismo. Pero existen testimonios reveladores concernientes a otras familias de la democracia, y algunos datan también del periodo iniciado en 1868 y aun de la República. A su vez, la práctica de las recomendaciones fue bastante común en ambas épocas, un recurso muy generalizado independientemente de las doctrinas que profesaran sus beneficiarios o solicitantes. Y los demócratas que pretendieron recabar el apoyo o la influencia de un notable tampoco hicieron distingos entre liberales y conservadores, siempre que encontraran buena disposición; igual que sucedió a la inversa, cuando el poderoso era un republicano. Aunque en ciudades como Oviedo no les hacía falta suplantar ni mediatizar la voluntad de sus convecinos, ya que disponían de un apoyo social que hasta sus adversarios reconocieron en muchas ocasiones. Lo que no fue óbice para que recompensaran a sus acólitos con empleos municipales, algo también muy común entonces.

En la España del periodo tratado aquí, un sinfín de objetivos únicamente podían conseguirse por la vía de la influencia. El canje de favores cimentaba las relaciones sociales. Ahora bien, por cada republicano que lograba un escaño merced a las redes clientelares, ¿cuántos disidentes vivían el hostigamiento pertinaz de ese mismo entramado caciquil? Las visiones simplificadas que presentan el republicanismo como uno e incorruptible deben matizarse, pero las faltas en las que muchos incurrieron contraviniendo sus discursos no fueron generales ni pueden desconectarse del contexto histórico en el que vivieron; y en cualquier caso, no deben hacer olvidar la marginación a la que se les relegó.

Hubo en Asturias, es cierto, un republicanismo vergonzante, como atinadamente lo denominó un contemporáneo, pero representaba un subconjunto del totum republicano. Otros valedores del ideario, al menos en público, se afanaron en exhibir una conducta ejemplar. El mismo año en que Castelar y Pidal allanaron la escalada parlamentaria de Celleruelo, 1883, Rafael $\mathrm{M}^{\mathrm{a}}$ de Labra dejó sobre la mesa del Congreso una propuesta que también firmó Manuel Pedregal y que trataba de cambiar aquellas partes de la ley que dificultaban la persecución de los delitos observados en los comicios, en particular en las elecciones municipales y provinciales. Se trata de un rasgo diferencial que no hay que subestimar. El hecho de que los republicanos no fueran completamente ajenos a las irregularidades tampoco significa que las practicaran en condiciones y niveles equiparables a los de sus adversarios; ni que todos los republicanismos y sus dirigentes y bases actuaran de igual modo. Es difícil presumir lo contrario sin obviar la apodíctica realidad bipartidista, que sistemáticamente alejó de los verdaderos centros de decisión a toda agrupación extraña al turno - republicana o no- y si le concedió una presencia marginal en las instituciones fue para velar por el espejismo de la representación. No es baladí subrayar que Celleruelo obtuvo una cartera ministerial sólo tras abjurar del republicanismo e ingresar en el Partido Liberal. 


\section{Agradecimientos}

Este trabajo ha sido viable gracias a una ayuda del Programa de FPU concedida por el Ministerio de Educación y Ciencia. Forma parte de una investigación doctoral que se ha beneficiado asimismo de los consejos de Francisco Erice, mi director de tesis, y de los miembros del tribunal que la juzgaron, Jean-Louis Guereña, Ángel Duarte y Jorge Uría. Quisiera, pues, manifestar un sincero reconocimiento hacia todos ellos. También agradezco francamente las anónimas observaciones de quienes han evaluado el artículo. Por último, deseo que conste mi gratitud expresa hacia dos personas que me han simplificado los últimos retoques: Alfonso Berenguer, de la Fundación Antonio Maura, que me facilitó el acceso a unos documentos que no habría podido consultar en la distancia, y Antonio López Villa, que me envió algunos de sus trabajos. 